\title{
Feeding diets varying in forage proportion and particle length to lactating dairy cows: II. Effects on duodenal flows and intestinal digestibility of amino acids
}

\author{
Y. L. Zhao, ${ }^{1,2}$ S. M. Yan, ${ }^{1}{ }^{\circ}$ K. A. Beauchemin, ${ }^{2}$ () and W. Z. Yang ${ }^{2 *}$ (1) \\ ${ }^{1}$ College of Animal Science, Inner Mongolia Agricultural University, Hohhot, 010018, China \\ ${ }^{2}$ Agriculture and Agri-Food Canada, Research Centre, Lethbridge, AB, T1J 4B1, Canada
}

\begin{abstract}
A study was conducted to evaluate the effects of forage-to-concentrate $(\mathrm{F}: \mathrm{C})$ ratio and forage particle length (FPL) on intake, duodenal flow, and digestibility of individual AA in the intestine of lactating dairy cows. The experiment was designed as a $4 \times 4$ Latin square with a $2 \times 2$ factorial arrangement of treatments using 4 lactating dairy cows (parity 2) with ruminal and duodenal cannulas. Low (35:65) and high (60:40) $\mathrm{F}: \mathrm{C}$ ratios (dry matter basis) were combined with 2 FPL of alfalfa silage (short vs. long; 7.9 vs. $19.1 \mathrm{~mm}$ ). Few interactions between F:C and FPL for duodenal flow and intestinal digestibility of AA occurred, but interactions were detected for intakes of several AA. Intake of essential AA and nonessential AA decreased with increasing $\mathrm{F}$ : $\mathrm{C}$, and the intake of several individual AA increased or decreased with increasing FPL. Increasing $\mathrm{F}$ : $\mathrm{C}$ decreased duodenal flows of essential AA, nonessential AA, and microbial AA due to consistent decreased flows of most individual AA (except Glu). Degradability of most individual AA in the rumen was not affected by $\mathrm{F}$ :C ratio or FPL except that the degradability of His was greater with high than low F:C diets, and the degradability of Ser was greater with long versus short FPL diets. However, the degradability of individual AA within diet varied considerably. Overall, F:C ratio and FPL did not affect intestinal digestibility of AA and rumen undegradable protein $\mathrm{AA}$, whereas the digestibility of individual AA in the intestine varied considerably regardless of dietary treatment. These results indicate that increasing $\mathrm{F}$ : $\mathrm{C}$ ratio decreased AA supply due to decreased flow of AA to the duodenum but altering FPL did not affect AA supply. The results also revealed the necessity to consider
\end{abstract}

Received September 18, 2019.

Accepted December 20, 2019.

*Corresponding author: wenzhu.yang@canada.ca both the flows and digestibility of individual AA when optimizing ration formulation to meet AA requirements of dairy cows.

Key words: forage-to-concentrate ratio, forage particle length, amino acid, dairy cow

\section{INTRODUCTION}

Increased feed prices, greater value placed on milk protein, and the environmental consequences of excess $\mathrm{N}$ feeding necessitate meeting the $\mathrm{AA}$ requirements of dairy cows for high milk protein yield while minimizing dietary CP content. Amount and quality of CP for intestinal absorption by dairy cows depend on microbial protein produced in the rumen and RUP that escapes the rumen, and their respective digestibilities (Clark et al., 1992). Microbial protein supply ranges from 34 to $89 \%$ (average of $59 \%$ ) of NAN flow to the duodenum (Clark et al., 1992; NRC, 2001), and increasing RUP supply increases intestinal absorption of both EAA and NEAA.

With the development of more refined nutrition models, it is possible to balance dairy cow diets for AA to improve protein use efficiency (Schwab, 2010). However, information on AA flows and digestibility as affected by diet is needed to refine model predictions. For example, the AA composition of microbial CP is often assumed to be constant (Clark et al., 1992), even though it is comprised of varying proportions of liquidand solid-associated bacteria and protozoa, each with varying AA composition (Yang et al., 2001; Sok et al., 2017). Using a factorial approach to predict AA flow from microbial CP, Sok et al. (2017) indicated that by assuming $33 \%$ fluid- and $50 \%$ particle-associated bacteria and $17 \%$ protozoa in mixed microbial CP, supply of Met and Thr was less and that of Ile, and Lys and Phe was 5 to $10 \%$ greater than average values for rumen bacteria (Clark et al., 1992). The dairy NRC (2001) assumes microbial protein is $80 \%$ digestible in the small intestine, without consideration of digestibility of individual $\mathrm{AA}$. 
To meet the AA demands of high-producing dairy cows, a sufficient amount of RUP must complement the AA supplied by microbial $\mathrm{CP}$ and endogenous sources (NRC, 2001). Studies have shown that an optimum AA profile in RUP positively affects milk protein yield (Schwab et al., 1992; Guinard and Rulquin, 1994). The dairy NRC (2001) model assumes similar AA profile of RUP and the original feedstuff, as well as similar digestibilities of the individual AA and the RUP. However, these assumptions may not always be true (Mjoun et al., 2010; Maxin et al., 2013). Individual AA profile of RUP and the original feed can differ, as can their digestibilities, depending upon feed type (Mjoun et al., 2010; Paz et al., 2014) and diet (Li et al., 2012b). Yet, NRC (2001) does not predict intestinal flow of individual EAA but rather AA requirements for milk production are restricted to MP supply.

The quantity of individual AA available in the intestine varies with DMI, AA composition of RUP, and microbial protein:RUP ratio (Rulquin and Vérité, 1993; Brito et al., 2014). These factors are affected by the composition of feed consumed and amount of microbial CP produced in the rumen (Overton et al., 1995). Grain processing (Yang and Beauchemin, 2004) and forage-to-concentrate $(\mathbf{F}: \mathbf{C})$ ratio (Khorasani et al., 2001; Brito et al., 2014) change microbial protein synthesis, flow of AA to duodenum, intestinal digestibility of AA and milk production. Adequate forage particle length (FPL) is necessary to maintain proper rumen function for high-energy-fed dairy cows. Decreased FPL inconsistently affects ruminal microbial protein synthesis (Krause et al., 2002; Beauchemin and Yang, 2005), depending on type of feed and $\mathrm{F}: \mathrm{C}$ ratio of the diet (Rode and Satter, 1988; Yang and Beauchemin, 2004).

Constant efficiency of utilization of MP and AA for maintenance and milk production is assumed by most protein models, which is likely not true (Arriola Apelo et al., 2014). Several studies (Chen et al., 2011; Haque et al., 2012; Osorio et al., 2013) report that the efficiency of MP utilization by dairy cows is affected by the proportion of EAA in MP. These findings indicate that a thorough understanding of the dynamics of AA metabolism could lead to improved prediction of AA requirements. Additionally, a previous study on measuring the flows of AA to the duodenum demonstrated the importance of evaluating multiple dietary factors (grain processing, F:C, and FPL) rather than a single dietary factor (Yang and Beauchemin, 2004). Studies using cannulated dairy cows to determine duodenal flows of AA (Brito et al., 2014) and the digestibility of individual AA in the intestine (Li et al., 2012a) are very limited.

Our hypothesis was that the flows of AA to the duodenum and their digestibility in the intestine vary with multiple dietary factors and manipulating these factors may improve the duodenal supply and intestinal digestibility of AA. The objectives of the study were to evaluate the effect of $\mathrm{F}: \mathrm{C}, \mathrm{FPL}$, and their interaction on intakes, duodenal flow, and intestinal digestibility of individual AA in mid-lactation dairy cows.

\section{MATERIALS AND METHODS}

\section{Cows and Diets}

The study was part of a larger experiment detailed elsewhere (Li et al., 2020); thus, only the relevant details are given herein. Four ruminally and duodenally cannulated lactating dairy cows were used in this experiment designed as a $4 \times 4$ Latin square with a 2 $\times 2$ factorial arrangement of treatments. Feeding and management of cows were outlined by Li et al. (2020). Cows averaged (mean \pm SD) $599 \pm 45 \mathrm{~kg}$ of BW, 135 $\pm 25 \mathrm{DIM}$, and $28.7 \pm 1.9 \mathrm{~kg}$ of milk yield and were cared for according to the Canadian Council on Animal Care (2009).

Cows were offered 1 of 4 diets consisting of short and long alfalfa silage (AS), combined with low (35:65) and high (60:40) F:C ratio (DM basis). The AS was the same as used in Li et al. (2020) with chemical composition (DM basis) of short versus long AS as follows: DM, 54.6 vs. $51.9 \%$; NDF, 44.9 vs. $45.4 \%$; and CP, 21.1 vs. $21.0 \%$, respectively. The diets were formulated using the NRC model (NRC, 2001) to supply sufficient energy and protein for a $600-\mathrm{kg}$ cow to produce $35 \mathrm{~kg} / \mathrm{d}$ of milk containing $3.5 \%$ fat and $3.2 \%$ protein (Supplemental Table S1; https://doi.org/10.3168/jds .2019-17607), and dietary AA composition is presented in Table 1. Each experimental period consisted of $14 \mathrm{~d}$ for adaptation to the diets and $7 \mathrm{~d}$ for data and sample collection. Feed offered and orts were measured and recorded daily during the last $7 \mathrm{~d}$ of the period to calculate feed intake. The collection and chemical analysis of feed samples including AS and TMR were described by Li et al. (2020).

\section{Duodenal Flow and Apparent Digestibility}

Duodenal flow and apparent digestibility of protein and AA were determined using $\mathrm{YbCl}_{3}$ (Rhône-Poulenc Inc., Shelton, CT) as the digestive marker. Ytterbium product was mixed into the concentrate portion of the diets to achieve an intake of approximately $1.5 \mathrm{~g}$ of $\mathrm{Yb} /$ cow per day. The ${ }^{15} \mathrm{~N}$-labeled ammonium sulfite $\left(10.6 \%\right.$ atom $\%{ }^{15} \mathrm{~N}$; Isotec, Miamisburg, $\left.\mathrm{OH}\right)$ was used to label ruminal microbes by continuously infusing into the rumen via the rumen cannula. Ruminal samples were collected once daily for $4 \mathrm{~d}$ to obtain a bacterial 
pellet. Duodenal samples were collected 4 times daily every $6 \mathrm{~h}$ moving ahead $2 \mathrm{~h}$ each day for the last $4 \mathrm{~d}$ of infusion. Fecal samples ( $200 \mathrm{~g}$ of wet weight) were collected from the rectum of each cow twice daily every $12 \mathrm{~h}$ moving ahead $2 \mathrm{~h}$ each day for the last $6 \mathrm{~d}$ of the period. This schedule provided twelve 2 -h samples of duodenal and fecal contents.

Ruminal samples were processed immediately to separate ruminal bacteria from protozoa and feed. The samples were squeezed through 4 layers of cheesecloth and the particles obtained by squeezing were blended ( $400 \mathrm{~g}$ of particles plus $400 \mathrm{~mL}$ of $0.9 \% \mathrm{NaCl}$ ) in a Waring blender (Waring Products Division, New Hartford, $\mathrm{CT}$ ) for $1 \mathrm{~min}$ and then squeezed through 4 layers of cheesecloth. Both filtrates from squeezed and strained homogenate were mixed, centrifuged at $800 \times g$ for 15 min at $4^{\circ} \mathrm{C}$ to remove protozoa and feed particles, and the supernatant was centrifuged at $27,000 \times g$ for 30 min at $4^{\circ} \mathrm{C}$ to obtain a mixed ruminal bacteria pellet. Bacterial pellets were accumulated by period, freezedried, ground using a mortar and pestle, and then further ground using a ball mill (Mixer Mill MM2000, Retsch, Haan, Germany) to a fine powder for determination of $\mathrm{N}$ content and ${ }^{15} \mathrm{~N}$ enrichment.

Each duodenal sample was split into 3 fractions that were pooled by cow within period and retained for ammonia analysis, DM determination after oven-drying

Table 1. Amino acid composition of the total mixed diet (\% of DM)

\begin{tabular}{|c|c|c|c|c|}
\hline \multirow[b]{3}{*}{ Item } & \multicolumn{4}{|c|}{$\mathrm{F}: \mathrm{C}^{1}$} \\
\hline & \multicolumn{2}{|c|}{$35: 65$} & \multicolumn{2}{|c|}{$60: 40$} \\
\hline & Short & Long & Short & Long \\
\hline $\operatorname{Arg}$ & 0.77 & 0.75 & 0.76 & 0.77 \\
\hline His & 0.52 & 0.52 & 0.48 & 0.48 \\
\hline Ile & 0.59 & 0.68 & 0.62 & 0.68 \\
\hline Leu & 1.69 & 1.51 & 1.78 & 1.63 \\
\hline Lys & 0.82 & 0.96 & 0.73 & 0.87 \\
\hline Met & 0.18 & 0.15 & 0.19 & 0.22 \\
\hline Phe & 0.70 & 0.82 & 0.70 & 0.84 \\
\hline Thr & 0.43 & 0.48 & 0.43 & 0.50 \\
\hline Val & 1.12 & 1.00 & 1.15 & 0.99 \\
\hline Ala & 0.74 & 0.90 & 0.83 & 0.90 \\
\hline Asp & 1.12 & 1.04 & 1.04 & 1.15 \\
\hline Cys & 0.19 & 0.19 & 0.22 & 0.24 \\
\hline Glu & 2.78 & 2.65 & 2.67 & 2.73 \\
\hline Gly & 0.90 & 0.78 & 0.94 & 0.70 \\
\hline Pro & 1.29 & 1.02 & 1.30 & 1.08 \\
\hline Ser & 0.94 & 1.09 & 0.82 & 1.00 \\
\hline Tyr & 0.57 & 0.55 & 0.58 & 0.61 \\
\hline Total AA & 15.35 & 15.09 & 15.24 & 15.39 \\
\hline EAA & 6.82 & 6.87 & 6.84 & 6.98 \\
\hline NEAA & 8.53 & 8.22 & 8.40 & 8.41 \\
\hline
\end{tabular}

${ }^{1}$ Alfalfa forage was harvested at a theoretical chop length of 19.1 or 7.9 $\mathrm{mm}$ for long- and short-cut silages, respectively. at $55^{\circ} \mathrm{C}$, or chemical analysis after freeze-drying. Fecal samples were immediately subsampled (about $50 \mathrm{~g}$ ), composited across sampling times for each cow and each period, dried at $55^{\circ} \mathrm{C}$, ground to pass a 1-mm sieve (standard model 4, Arthur Thomas Co., Philadelphia, PA), and stored for chemical analysis.

\section{Chemical Analyses}

Feed DM was determined by oven-drying at $55^{\circ} \mathrm{C}$ for $48 \mathrm{~h}$. Analytical DM content of the samples was determined by drying at $135^{\circ} \mathrm{C}$ for $2 \mathrm{~h}$ (AOAC International, 2005). The OM content was calculated as the difference between DM and ash contents, with ash determined by combustion at $550^{\circ} \mathrm{C}$ overnight. The NDF, ADF, starch, and total lipids (i.e., ether extract) in feed samples were determined as described by Li et al. (2020). Contents of digestive markers in the duodenal and fecal samples were determined using inductively coupled plasma optical emission spectroscopy according to the AOAC method (AOAC International, 2005) modified such that no $\mathrm{CaCl}$ for $\mathrm{Yb}$ determination was used during sample digestion. Content of $\mathrm{N}$ in the samples was determined by flash combustion (model 1500, Carlo Erba Instruments, Milan, Italy) and enrichment of ${ }^{15} \mathrm{~N}$ in the rumen bacterial, duodenal, and fecal samples was analyzed with isotope ratio mass spectrometry (VG Isotech, Middlewich, England). Amino acids in feed and digestive samples were analyzed as the phenylisothiocyanate derivatives by HPLC (WM02, Waters Corp., Milford, MA) according to the procedure of Hagen et al. (1989), with minor modifications in the oxidation step (Li et al., 2012b). In brief, a sample containing $10 \mathrm{mg}$ of protein was oxidized with $5 \mathrm{~mL}$ of performic acid. One milliliter of concentrated $\mathrm{HCl}$ and 3 drops of 1-octanol were added to allow samples to sit at $20^{\circ} \mathrm{C}$ before evaporation the next day. For derivatization, 40 $\mu \mathrm{L}$ of a derivatized $\mathrm{MeOH}$-water-triethylamine $(2: 2: 1)$ solution was added into the derivatization tubes. The contents were dried by adding the phenylisothiocyanate mixture at $20^{\circ} \mathrm{C}$ at atmospheric pressure.

\section{Calculations and Statistical Analyses}

Flows of $\mathrm{CP}$ and $\mathrm{AA}$ to the duodenum or the excretion of $\mathrm{CP}$ and $\mathrm{AA}$ in feces were calculated by multiplying $\mathrm{DM}$ flow by the respective concentration of $\mathrm{CP}$ or AA in duodenal or fecal DM. The flows of DM to the duodenum and DM excreted in feces were calculated as described by Li et al. (2020). Endogenous N was estimated as $1.9 \mathrm{~g}$ of $\mathrm{N} / \mathrm{kg}$ of DMI for duodenal flows and $4.8 \mathrm{~g}$ of N/kg of DMI for feces (NRC, 2001), and was subtracted from the duodenal and fecal flows of CP, 
respectively. Microbial protein flow to the duodenum and excreted in feces for each cow was estimated by the ratio of ${ }^{15} \mathrm{~N}$ flow at the duodenum or the feces to ${ }^{15} \mathrm{~N}$ concentration of mixed ruminal bacteria. Flows of microbial AA to the duodenum and to the feces were estimated based on the respective microbial protein flow and AA composition of bacterial samples isolated from ruminal contents. Therefore, the flows of feed AA origin in the duodenal and fecal samples were calculated as the difference between total and microbial AA flows.

Data for intakes, duodenal flows of protein and AA, and ruminal degradability and intestinal digestibility of AA were analyzed using the Mixed procedure of SAS (SAS Institute Inc., Cary, NC) in a $4 \times 4$ Latin square design. The model included the fixed effect of $\mathrm{F}: \mathrm{C}$, FPL, and the interaction between F:C and FPL, and random effects of experimental period and cow. The estimation method was restrictive maximum likelihood and the degrees of freedom method was Kenward-Rogers. The PDIFF option adjusted by the Tukey method was included in the LSMEANS statement to account for multiple comparisons among treatments. Effects of the factors were declared significant at $P \leq 0.05$ and tendencies were discussed at $P \leq 0.10$, unless otherwise noted.

\section{RESULTS AND DISCUSSION}

\section{Intake of $A A$}

Intake of $\mathrm{CP}$ decreased $(P<0.01)$ with increasing dietary $\mathrm{F}: \mathrm{C}$ ratio, and as a result, intakes of total AA, EAA, NEAA, and most of individual AA decreased, except intakes of Leu, Met, Ala, Cys, and Tyr, which did not differ (Table 2). Lowered CP intake associated with feeding the high $\mathrm{F}$ : $\mathrm{C}$ diets was due to decreased DMI (24.9 vs. $22.5 \mathrm{~kg} / \mathrm{d}$ for low vs. high F:C diets; $\mathrm{Li}$ et al., 2020), which is consistent with previous studies (Li et al., 2012a; Arndt et al., 2014) that report increasing $\mathrm{F}$ :C ratio decreased DMI of dairy cows fed either barley- or corn-grain-based diets. The decrease in DMI when feeding high $\mathrm{F}$ : $\mathrm{C}$ diets decreased $(P<$ 0.01 ) intakes of EAA, NEAA, and total AA because the dietary concentration of EAA, NEAA, and total AA (average of $6.9,8.4$, and $15.3 \%$ of dietary DM, respectively) did not differ between low and high F:C diets.

Increased FPL did not alter the intakes of CP, total AA, EAA, NEAA, and individual AA (Table 2). However, interactions between $\mathrm{F}: \mathrm{C}$ ratio and $\mathrm{FPL}$ on intakes of $\operatorname{Arg}(P=0.06)$, Ile $(P=0.05)$, Ala $(P=$ $0.04)$, Gly $(P=0.08)$, and Pro $(P=0.05)$ occurred.

Table 2. Effects of forage-to-concentrate ratio (F:C) and forage particle length (FPL) on AA intake

\begin{tabular}{|c|c|c|c|c|c|c|c|c|}
\hline \multirow[b]{3}{*}{ Item } & \multicolumn{4}{|c|}{$\mathrm{F}: \mathrm{C}^{1}$} & \multirow[b]{3}{*}{ SEM } & \multirow{2}{*}{\multicolumn{3}{|c|}{$P$-value }} \\
\hline & \multicolumn{2}{|c|}{$35: 65$} & \multicolumn{2}{|c|}{ 60: 40} & & & & \\
\hline & Short & Long & Short & Long & & $\mathrm{FC}$ & FPL & $\mathrm{F}: \mathrm{C} \times \mathrm{FPL}$ \\
\hline $\begin{array}{l}\text { Intake of CP, g/d } \\
\mathrm{AA}, \mathrm{g} / \mathrm{d}\end{array}$ & 4,483 & 4,577 & 3,935 & 3,913 & 413.8 & $<0.01$ & 0.79 & 0.66 \\
\hline Arg & 176 & 179 & 158 & 146 & 6.9 & $<0.01$ & 0.21 & 0.06 \\
\hline His & 118 & 120 & 99 & 95 & 4.2 & $<0.01$ & 0.61 & 0.12 \\
\hline Ile & $133^{\mathrm{b}}$ & $153^{\mathrm{a}}$ & $133^{\mathrm{b}}$ & $121^{\mathrm{b}}$ & 5.8 & $<0.01$ & 0.15 & 0.05 \\
\hline Leu & 348 & 368 & 345 & 331 & 17.5 & 0.12 & 0.45 & 0.31 \\
\hline Lys & 191 & 214 & 159 & 147 & 6.8 & $<0.01$ & 0.23 & 0.25 \\
\hline Met & 36 & 38 & 40 & 39 & 2.4 & 0.23 & 0.17 & 0.18 \\
\hline Phe & 168 & 176 & 159 & 143 & 6.7 & $<0.01$ & 0.19 & 0.15 \\
\hline Thr & 101 & 106 & 94 & 86 & 3.8 & $<0.01$ & 0.24 & 0.23 \\
\hline Val & 233 & 235 & 213 & 203 & 10.8 & $<0.01$ & 0.21 & 0.14 \\
\hline Ala & $172^{\mathrm{b}}$ & $199^{\mathrm{a}}$ & $167^{\mathrm{b}}$ & $174^{\mathrm{b}}$ & 8.0 & 0.08 & 0.08 & 0.04 \\
\hline Asp & 229 & 240 & 207 & 204 & 9.9 & $<0.01$ & 0.31 & 0.11 \\
\hline Cys & 47 & 46 & 44 & 46 & 2.1 & 0.09 & 0.29 & 0.29 \\
\hline Glu & 649 & 642 & 577 & 555 & 22.9 & $<0.01$ & 0.25 & 0.86 \\
\hline Gly & 189 & 193 & 180 & 155 & 7.7 & $<0.01$ & 0.18 & 0.08 \\
\hline Pro & $247^{\mathrm{a}}$ & $257^{\mathrm{a}}$ & $248^{\mathrm{a}}$ & $209^{\mathrm{b}}$ & 12.2 & $<0.01$ & 0.11 & 0.05 \\
\hline Ser & 211 & 233 & 152 & 176 & 9.6 & $<0.01$ & 0.08 & 0.22 \\
\hline Tyr & 128 & 126 & 128 & 110 & 5.4 & 0.34 & 0.94 & 0.61 \\
\hline Total AA & 3,376 & 3,525 & 3,103 & 2,940 & 139.0 & $<0.01$ & 0.73 & 0.20 \\
\hline EAA & 1,504 & 1,584 & 1,400 & 1,311 & 62.8 & $<0.01$ & 0.63 & 0.08 \\
\hline NEAA & 1,872 & 1,936 & 1,703 & 1,628 & 76.4 & $<0.01$ & 0.34 & 0.41 \\
\hline
\end{tabular}

$\overline{\mathrm{a}, \mathrm{b}}$ Least squares means within a row with different superscripts differ $(P<0.05)$.

${ }^{1}$ Alfalfa forage was harvested at a theoretical chop length of 19.1 or $7.9 \mathrm{~mm}$ for long- and short-cut silages, respectively. 
The intakes of Ile and Ala were greater $(P=0.05)$ with long versus short FPL at low F:C without being affected by FPL at high F:C. In contrast, intakes of Arg, Gly, and Pro did not differ at low F:C but tended $(P=0.08)$ to decrease (Arg, Gly) or decreased (Pro; $P$ $=0.05)$ with long FPL at high F:C. The lack of overall differences in intakes of $\mathrm{CP}$ and $\mathrm{AA}$ due to FPL was expected because the dietary formulation was the same between short and long FPL, and the intake of CP was not affected by FPL. The variation of individual AA intakes among diets might have resulted from combined variation in DMI, AA profiles of short and long FPL AS, and possibly sorting for long particles due to low rumen $\mathrm{pH}$ of cows fed the low F:C diets (Kononoff et al., 2003), although not measured in the present study. Nevertheless, it is clear that AA intake is not a very meaningful measurement of actual intestinal supply of AA in dairy cattle.

\section{Flows of AA to the Duodenum}

Interactions of $\mathrm{F}: \mathrm{C}$ and $\mathrm{FPL}$ on flows of $\mathrm{CP}$ and $\mathrm{AA}$ (total, microbial, and individual) to the duodenum were overall not significant except that increased dietary FPL tended $(P=0.09)$ to decrease the flows of Tyr for low F:C diets without effects for high F:C diets (Table 3). Flows to the duodenum of CP, total AA, EAA, NEAA, microbial and feed AA, as well as individual AA, decreased $(P<0.05)$ with increasing $\mathrm{F}: \mathrm{C}$ ratio in the diets except for the flow of Glu, which did not differ among diets. Effects of dietary $\mathrm{F}$ : $\mathrm{C}$ on the flows of $\mathrm{CP}$ and $\mathrm{AA}$ to the duodenum may be affected by DMI and the amount of OM degraded in the rumen. Rode et al. (1985) and Moorby et al. (2006) reported linear decreases of DMI, amount of rumen truly degraded OM (RDOM), and flows of microbial $\mathrm{N}$ and NAN to the duodenum with increasing $\mathrm{F}$ : $\mathrm{C}$ ratios of dairy cow diets. Several studies (Clark et al., 1992; Ipharraguerre and Clark, 2005, 2014) reviewed several digestion studies with diets containing a wide range of $\mathrm{F}: \mathrm{C}$, and reported linearly decreased flows of microbial $\mathrm{N}$, feed $\mathrm{N}$, and NAN to the duodenum with increasing F:C ratio. The authors suggested that altering DMI is one of the most important mechanisms of changing the intestinal availability of AA to dairy cows because DMI affects both microbial protein synthesis and the quantity of feed protein escaping ruminal degradation. In the present study, the duodenal flows of microbial $\mathrm{N}, \mathrm{RUP}$ and total NAN were decreased by 19, 11, and $15 \%$, respectively, when feeding high versus low $\mathrm{F}: \mathrm{C}$ diets, due to $13 \%$ reduction of DMI. However, there is likely no single optimum $\mathrm{F}$ : $\mathrm{C}$ ratio that maximizes duodenal flows of NAN and AA because the composition of forages and concentrates also contribute to flows (Clark et al., 1992). Overton et al. (1995) reported greater passage of AA to the duodenum when either ground shelled corn or steam-rolled barley was fed as the sole grain starch compared with a mixture of corn and barley. In that study, greater passage of AA was due to greater DMI and greater RUP when feeding corn, whereas microbial $\mathrm{N}$ was greater when feeding barley.

Flows of CP and AA overall did not differ between short and long FPL (Table 3), which can be attributed to ruminal protein degradability and amount of RDOM $(\mathrm{kg} / \mathrm{d})$ being similar for these diets (Li et al., 2020). These results are in agreement with several other studies that report no differences in microbial and total duodenal flows of EAA, NEAA, or total AA due to FPL (Firkins et al., 1986; Yang and Beauchemin, 2004; Li et al., 2012a). Krause et al. (2002) found that the effect of AS particle length on microbial N supply depended upon corn processing (i.e., high moisture vs. dry rolling); the microbial $\mathrm{N}$ supply increased with a high-moisture corn diet but decreased with a dry-rolled corn diet when dietary FPL was increased. This effect was due to greater starch intake with the high-moisture corn versus dry-rolled corn diet. Thus, factors that affect energy availability in the rumen ultimately determine microbial protein production.

\section{Ruminal Degradability and Intestinal Digestibility of $A A$}

No interaction was observed between F:C and FPL on ruminal degradability of AA, except for Tyr $(P=$ 0.02), which was greater with long than short FPL for the low F:C diet but similar for the high F:C diet (Table 4). Furthermore, the degradability of most individual AA in the rumen was not affected by $\mathrm{F}: \mathrm{C}$ ratio or $\mathrm{FPL}$, except that the degradability of His was greater $(P<$ 0.01 ) with high than low F:C diets, and that of Ser was greater $(P=0.02)$ with long versus short FPL diets. However, the variation of individual AA degradability within diet was large (e.g., ranging from 42 to $80 \%$ for the low F:C, long FPL diet). Ruminal AA degradability of feeds is often measured using the in situ technique by incubating individual feeds in the rumen for a fixed time (often 16 h; Mjoun et al., 2010; Paz et al., 2014), whereas in vivo ruminal AA degradability of diets is seldom reported because there is no direct technique to determine the flows of RUP AA to the duodenum. Lack of overall differences in ruminal AA degradability among diets, but large variation within diet in the present study contrasts with literature reports in which considerable variation of ruminal individual AA degradability (\%) has been reported among feeds (5 to 70\%; White et al., 2017) with less variation among individual AA within a feed (Paz et al., 2014; White et al., 
Table 3. Effects of forage-to-concentrate ratio (F:C) and forage particle length (FPL) on duodenal flows of AA

\begin{tabular}{|c|c|c|c|c|c|c|c|c|}
\hline \multirow[b]{3}{*}{ Item } & \multicolumn{4}{|c|}{$\mathrm{F}: \mathrm{C}^{1}$} & \multirow[b]{3}{*}{ SEM } & \multirow{2}{*}{\multicolumn{3}{|c|}{$P$-value }} \\
\hline & \multicolumn{2}{|c|}{$35: 65$} & \multicolumn{2}{|c|}{$60: 40$} & & & & \\
\hline & Short & Long & Short & Long & & $\mathrm{FC}$ & FPL & $\mathrm{F}: \mathrm{C} \times \mathrm{FPL}$ \\
\hline \multicolumn{9}{|l|}{$\mathrm{AA}, \mathrm{g} / \mathrm{d}$} \\
\hline Arg & 140 & 131 & 109 & 114 & 9.4 & 0.02 & 0.96 & 0.49 \\
\hline His & 102 & 101 & 70 & 69 & 7.1 & $<0.01$ & 0.77 & 0.73 \\
\hline Ile & 177 & 140 & 112 & 118 & 15.5 & $<0.01$ & 0.22 & 0.12 \\
\hline Leu & 331 & 384 & 291 & 302 & 22.3 & 0.03 & 0.18 & 0.34 \\
\hline Lys & 184 & 209 & 149 & 145 & 16.5 & $<0.01$ & 0.48 & 0.39 \\
\hline Met & 45 & 38 & 30 & 36 & 2.3 & $<0.01$ & 0.35 & 0.11 \\
\hline Phe & 172 & 169 & 121 & 125 & 13.8 & $<0.01$ & 0.98 & 0.70 \\
\hline Thr & 117 & 126 & 89 & 79 & 12.0 & $<0.01$ & 0.98 & 0.26 \\
\hline Val & 218 & 246 & 189 & 164 & 22.0 & 0.02 & 0.93 & 0.21 \\
\hline Ala & 183 & 182 & 141 & 138 & 19.3 & 0.05 & 0.72 & 0.78 \\
\hline Asp & 264 & 245 & 185 & 176 & 25.1 & 0.02 & 0.60 & 0.15 \\
\hline Cys & 45 & 45 & 35 & 34 & 3.1 & $<0.01$ & 0.96 & 0.96 \\
\hline Glu & 364 & 291 & 317 & 319 & 43.8 & 0.14 & 0.70 & 0.76 \\
\hline Gly & 161 & 151 & 127 & 128 & 15.1 & 0.05 & 0.71 & 0.62 \\
\hline Pro & 199 & 224 & 173 & 167 & 15.3 & 0.02 & 0.54 & 0.31 \\
\hline Ser & 193 & 174 & 137 & 120 & 15.2 & $<0.01$ & 0.15 & 0.82 \\
\hline Tyr & 141 & 119 & 108 & 118 & 11.3 & 0.08 & 0.49 & 0.09 \\
\hline Total AA & 3,035 & 3,071 & 2,393 & 2,353 & 211.1 & 0.02 & 0.95 & 0.93 \\
\hline EAA & 1,486 & 1,541 & 1,159 & 1,151 & 95.5 & $<0.01$ & 0.78 & 0.71 \\
\hline NEAA & 1,550 & 1,531 & 1,223 & 1,202 & 120.9 & 0.03 & 0.86 & 0.98 \\
\hline \multicolumn{9}{|c|}{ Microbial, g/d } \\
\hline Total AA & 1,795 & 1,618 & 1,278 & 1,273 & 189.1 & $<0.01$ & 0.22 & 0.40 \\
\hline EAA & 880 & 786 & 628 & 604 & 89.2 & $<0.01$ & 0.17 & 0.45 \\
\hline NEAA & 915 & 832 & 650 & 669 & 100.8 & $<0.01$ & 0.28 & 0.37 \\
\hline \multicolumn{9}{|c|}{ Flows of $\mathrm{CP}, \mathrm{g} / \mathrm{d}$} \\
\hline Total & 4,327 & 4,032 & 3,345 & 3,340 & 277.7 & $<0.01$ & 0.33 & 0.35 \\
\hline Feed & 1,990 & 1,753 & 1.555 & 1,446 & 218.5 & $<0.01$ & 0.13 & 0.54 \\
\hline Microbial & 2,219 & 2,174 & 1,670 & 1,795 & 204.9 & $<0.01$ & 0.78 & 0.46 \\
\hline
\end{tabular}

${ }^{1}$ Alfalfa forage was harvested at a theoretical chop length of 19.1 or $7.9 \mathrm{~mm}$ for long- and short-cut silages, respectively.

2017). The large variation of AA degradability within a diet in the present study may be explained by variation in ingredients comprising the diets, which were formulated with various feed protein sources that would have contributed different AA and AA degradation profiles. The reason for greater degradability of His with high versus low F:C diets is not quite clear. However, White et al. (2017) reported greater degradability of His for forage $(74.1 \%)$ than grain $(67.1 \%)$, which is consistent with the observed increase in His degradability with increasing ratio of $\mathrm{F}: \mathrm{C}$ in the present study. The ruminal degradability of total AA was greater (from 59 to $64 \%$ ) than the degradability of CP (from 55 to $58 \%$; Li et al., 2020), which was expected because the AA degradability was corrected for endogenous $\mathrm{N}$ but not for the degradability of CP.

Overall, feeding low versus high F:C diets did not affect digestibility of total AA, EAA, NEAA, or most individual $\mathrm{AA}$ in the intestine (Table 5), with the exception of an interaction between F:C and FPL (Met; $P$ $=0.04)$. Digestibility of Met was lower $(P=0.04)$ with long versus short FPL for low F:C diets, yet digestibil- ity of Met did not differ due to particle length for high F:C diets. Similarly, the intestinal digestibility of RUP AA (total, EAA, NEAA, and the individual AA) did not differ between low and high $\mathrm{F}: \mathrm{C}$ diets (Table 6) except for a tendency $(P=0.06)$ for greater digestibility of Glu with high versus low F:C diets. A tendency $(P$ $=0.09$ ) was also observed for a $\mathrm{F}: \mathrm{C}$ by FPL interaction for Val digestibility due to lower digestibility with long versus short FPL in the high F:C diet without difference between short and long FPL in the low F:C diet. The general lack of effect of $\mathrm{F}: \mathrm{C}$ on the digestibility of AA in the intestine is consistent with our previous study with dairy cows fed diets containing barley, mixed silage (corn and barley), and hay (Yang and Beauchemin, 2004). However, it is inconsistent with other studies in sheep fed a barley- and straw-based diet (Ben-Ghedalia and Solomon, 1988) or in dairy cows fed barley and AS (Li et al., 2012a). Decreased AA digestibility in the intestine with increasing $\mathrm{F}$ : $\mathrm{C}$ in those studies may have resulted from enhanced particle-associated bacteria production relative to liquid-associated bacteria (i.e., adherence to forage particles may act as a protection 
Table 4. Effects of forage-to-concentrate ratio (F:C) and forage particle length (FPL) on AA degradability in the rumen

\begin{tabular}{|c|c|c|c|c|c|c|c|c|}
\hline \multirow[b]{3}{*}{ Item } & \multicolumn{4}{|c|}{$\mathrm{F}: \mathrm{C}^{1}$} & \multirow[b]{3}{*}{ SEM } & \multirow{2}{*}{\multicolumn{3}{|c|}{$P$-value }} \\
\hline & \multicolumn{2}{|c|}{$35: 65$} & \multicolumn{2}{|c|}{$60: 40$} & & & & \\
\hline & Short & Long & Short & Long & & $\mathrm{FC}$ & FPL & $\mathrm{F}: \mathrm{C} \times \mathrm{FPL}$ \\
\hline \multicolumn{9}{|c|}{$\mathrm{AA}, \%$ of $\mathrm{AA}$ intake } \\
\hline Arg & 65.1 & 66.8 & 68.2 & 58.6 & 4.63 & 0.59 & 0.42 & 0.25 \\
\hline His & 49.0 & 44.3 & 58.2 & 59.4 & 4.76 & $<0.01$ & 0.43 & 0.62 \\
\hline Ile & 62.7 & 70.1 & 72.0 & 67.3 & 8.33 & 0.53 & 0.40 & 0.18 \\
\hline Leu & 54.2 & 41.9 & 51.2 & 44.8 & 7.18 & 0.48 & 0.09 & 0.33 \\
\hline Lys & 59.4 & 51.0 & 54.4 & 65.2 & 7.09 & 0.52 & 0.87 & 0.20 \\
\hline Met & 71.1 & 71.6 & 76.5 & 77.4 & 6.73 & 0.79 & 0.63 & 0.22 \\
\hline Phe & 62.8 & 64.2 & 69.9 & 71.3 & 4.58 & 0.11 & 0.74 & 0.99 \\
\hline Thr & 69.4 & 60.8 & 71.1 & 75.3 & 7.51 & 0.45 & 0.61 & 0.25 \\
\hline Val & 62.8 & 51.0 & 57.7 & 59.3 & 9.85 & 0.47 & 0.28 & 0.22 \\
\hline Ala & 64.5 & 67.7 & 67.7 & 71.2 & 8.24 & 0.69 & 0.69 & 0.95 \\
\hline Asp & 72.6 & 72.9 & 78.6 & 85.9 & 9.08 & 0.41 & 0.74 & 0.68 \\
\hline Cys & 46.9 & 41.6 & 51.8 & 56.1 & 5.59 & 0.11 & 0.93 & 0.41 \\
\hline Glu & 73.1 & 63.3 & 68.1 & 70.3 & 5.25 & 0.80 & 0.50 & 0.28 \\
\hline Gly & 78.8 & 73.0 & 75.3 & 70.4 & 3.02 & 0.15 & 0.12 & 0.33 \\
\hline Pro & 56.5 & 45.4 & 52.4 & 44.2 & 7.59 & 0.46 & 0.09 & 0.59 \\
\hline Ser & 46.6 & 66.6 & 47.6 & 69.5 & 8.61 & 0.78 & 0.02 & 0.89 \\
\hline Tyr & $64.6^{\mathrm{b}}$ & $79.7^{\mathrm{a}}$ & $72.3^{\mathrm{ab}}$ & $63.9^{\mathrm{b}}$ & 5.13 & 0.38 & 0.46 & 0.02 \\
\hline Total AA & 63.6 & 58.5 & 63.9 & 64.0 & 5.35 & 0.57 & 0.61 & 0.60 \\
\hline EAA & 59.8 & 52.0 & 61.2 & 59.4 & 5.38 & 0.94 & 0.38 & 0.61 \\
\hline NEAA & 66.6 & 62.9 & 66.0 & 67.7 & 5.16 & 0.72 & 0.86 & 0.64 \\
\hline
\end{tabular}

${ }^{\mathrm{a}, \mathrm{b}}$ Least squares means within a row with different superscripts differ $(P<0.05)$.

${ }^{1}$ Alfalfa forage was harvested at a theoretical chop length of 19.1 or $7.9 \mathrm{~mm}$ for long- and short-cut silages, respectively.

mechanism; Ben-Ghedalia and Solomon, 1988) or a change in the relative proportion of microbial AA to dietary AA in duodenal protein. The intestinal digestibility of microbial AA is typically less than that of dietary AA (Mjoun et al., 2010; Fonseca et al., 2014). Moorby et al. (2006) reported linearly increased microbial $\mathrm{N}$ proportion (\% of total $\mathrm{N}$ ) in duodenal $\mathrm{N}$ flows and linearly decreased total-tract $\mathrm{N}$ digestibility with increasing F:C from 35:65, 50:50, 65:35 to 80:20 in dairy cow diets. Similarly, Li et al. (2012a) observed slightly increased microbial AA proportion (\% of total AA) from 55.1 to $57.3 \%$ in duodenal protein and a tendency of decreased total AA intestinal digestibility from 68.1 to $64.0 \%$ with increased $\mathrm{F}$ :C from 35:65 to 60:40 in dairy cows. However, in the present study, all diets except for the one with low F:C and short FPL ( $59.1 \%$ of total AA) had a similar microbial AA proportion (average of $53.4 \%$ of total AA; Table 3), whereas the greater microbial AA proportion for the diet with low F:C and short FPL (59.1 vs. $53.4 \%$ of total AA) did not show a reduction of intestinal digestibility of AA compared with other diets. Our results indicate that the intestinal digestibility of AA does not vary extensively due to the ratio of microbial protein to RUP. Rather, AA digestibility in the intestine varies mainly due to microbial composition (bacteria vs. protozoa) and the composition of RUP, which depends upon the feed source (Hvelplund and Hesselholt, 1987; White et al., 2017; Fessenden et al., 2019).

Feeding diets containing long versus short FPL did not affect the intestinal digestibility of total AA, EAA, NEAA, and most individual AA except that the digestibility of Ile $(P=0.02)$, Val $(P=0.06)$, and Cys $(P=$ 0.05 ) was less with long versus short FPL (Table 5). No effects were observed of dietary FPL on the intestinal digestibility of RUP AA, including total, EAA, NEAA, and individual AA (Table 6). The digestibility of AA in the intestine varied among individual AA and ranged from $73 \%$ for Ile, Thr, and Tyr to $88 \%$ for Leu and Pro, which is consistent with other studies (Li et al., 2012a; Fessenden et al., 2017; White et al., 2017). The lack of dietary effect of FPL on the intestinal digestibility of $\mathrm{AA}$ is in accordance with the similar duodenal flows of $\mathrm{NDF}$ and $\mathrm{CP}$, and the ratio of microbial $\mathrm{N}$ to dietary $\mathrm{N}$ between short and long FPL.

Digestibility of individual AA in the intestine varied among AA and ranged (average of 4 diets) from $77 \%$ for Thr, Ala, and Asp to $>85 \%$ for Arg, Leu, Pro, and Ser. Additionally, the digestibility of individual RUP AA in the intestine varied among AA and ranged (average of 4 diets) from $77 \%$ for Ile to $>85 \%$ for Arg, Leu, Thr, Val, Pro, and Ser. The results indicated slightly higher 
Table 5. Effects of forage-to-concentrate ratio (F:C) and forage particle length (FPL) on AA digestibility in the intestine

\begin{tabular}{|c|c|c|c|c|c|c|c|c|}
\hline \multirow[b]{3}{*}{ Item } & \multicolumn{4}{|c|}{$\mathrm{F}: \mathrm{C}^{1}$} & \multirow[b]{3}{*}{ SEM } & \multirow{2}{*}{\multicolumn{3}{|c|}{$P$-value }} \\
\hline & \multicolumn{2}{|c|}{$35: 65$} & \multicolumn{2}{|c|}{$60: 40$} & & & & \\
\hline & Short & Long & Short & Long & & $\mathrm{FC}$ & FPL & $\mathrm{F}: \mathrm{C} \times \mathrm{FPL}$ \\
\hline \multicolumn{9}{|c|}{ AA, $\%$ of duodenal flow } \\
\hline Arg & 85.9 & 83.6 & 86.1 & 84.7 & 2.18 & 0.58 & 0.22 & 0.66 \\
\hline His & 82.8 & 79.7 & 81.1 & 79.3 & 3.37 & 0.69 & 0.35 & 0.72 \\
\hline Ile & 83.0 & 72.9 & 81.2 & 77.1 & 3.62 & 0.60 & 0.02 & 0.22 \\
\hline Leu & 87.7 & 86.1 & 87.4 & 87.7 & 2.04 & 0.70 & 0.67 & 0.53 \\
\hline Lys & 78.8 & 80.1 & 80.8 & 77.7 & 2.90 & 0.95 & 0.75 & 0.42 \\
\hline Met & $82.7^{\mathrm{a}}$ & $71.6^{\mathrm{b}}$ & $80.2^{\mathrm{a}}$ & $82.1^{\mathrm{a}}$ & 3.51 & 0.16 & 0.11 & 0.04 \\
\hline Phe & 81.7 & 77.6 & 78.2 & 77.1 & 3.50 & 0.46 & 0.34 & 0.57 \\
\hline Thr & 74.6 & 80.6 & 79.6 & 73.1 & 3.76 & 0.69 & 0.93 & 0.08 \\
\hline Val & 84.1 & 80.9 & 86.2 & 79.9 & 2.32 & 0.81 & 0.06 & 0.51 \\
\hline Ala & 77.3 & 74.2 & 81.0 & 76.8 & 3.74 & 0.37 & 0.29 & 0.88 \\
\hline Asp & 77.6 & 76.7 & 79.2 & 74.8 & 3.60 & 0.96 & 0.37 & 0.54 \\
\hline Cys & 84.6 & 80.3 & 83.7 & 78.9 & 2.67 & 0.55 & 0.05 & 0.88 \\
\hline Glu & 80.1 & 78.1 & 82.3 & 82.6 & 3.29 & 0.26 & 0.73 & 0.68 \\
\hline Gly & 78.9 & 76.7 & 81.0 & 78.2 & 2.77 & 0.36 & 0.22 & 0.86 \\
\hline Pro & 86.0 & 87.3 & 88.4 & 85.6 & 1.88 & 0.88 & 0.69 & 0.24 \\
\hline Ser & 86.8 & 86.2 & 87.1 & 81.5 & 2.44 & 0.25 & 0.14 & 0.21 \\
\hline Tyr & 82.4 & 73.1 & 80.3 & 78.8 & 3.45 & 0.58 & 0.13 & 0.24 \\
\hline Total AA & 82.6 & 80.2 & 83.2 & 80.8 & 2.62 & 0.75 & 0.25 & 0.98 \\
\hline $\mathrm{EAA}$ & 83.5 & 81.1 & 83.6 & 81.2 & 2.47 & 0.94 & 0.23 & 0.99 \\
\hline NEAA & 81.6 & 79.3 & 82.9 & 80.3 & 2.81 & 0.59 & 0.29 & 0.96 \\
\hline \multicolumn{9}{|c|}{ Intestinal AA digested, $\mathrm{g} / \mathrm{d}$} \\
\hline Total AA & 2,522 & 2,474 & 1,979 & 1,900 & 215.7 & 0.04 & 0.76 & 0.94 \\
\hline EAA & 1,244 & 1,256 & 967 & 935 & 97.6 & 0.02 & 0.92 & 0.80 \\
\hline NEAA & 1,278 & 1,218 & 1,012 & 965 & 122.1 & 0.06 & 0.66 & 0.96 \\
\hline
\end{tabular}

${ }^{\mathrm{a}, \mathrm{b}}$ Least squares means within a row with different superscripts differ $(P<0.05)$.

${ }^{1}$ Alfalfa forage was harvested at a theoretical chop length of 19.1 or $7.9 \mathrm{~mm}$ for long- and short-cut silages, respectively.

Table 6. Effects of forage-to-concentrate ratio (F:C) and forage particle length (FPL) on RUP AA digestibility in the intestine

\begin{tabular}{|c|c|c|c|c|c|c|c|c|}
\hline Item & \multicolumn{4}{|c|}{$\mathrm{F}: \mathrm{C}^{1}$} & SEM & \multicolumn{3}{|c|}{$P$-value } \\
\hline \multicolumn{9}{|c|}{ AA, $\%$ of duodenal flow } \\
\hline Arg & 89.6 & 91.4 & 90.8 & 89.0 & 3.97 & 0.23 & 0.34 & 0.24 \\
\hline His & 83.9 & 79.6 & 82.3 & 78.6 & 4.21 & 0.69 & 0.25 & 0.93 \\
\hline Lys & 76.6 & 78.0 & 83.7 & 76.3 & 7.44 & 0.22 & 0.90 & 0.21 \\
\hline Met & 85.1 & 80.1 & 84.6 & 80.8 & 8.51 & 0.71 & 0.36 & 0.75 \\
\hline Phe & 77.4 & 79.8 & 83.7 & 76.7 & 9.31 & 0.73 & 0.63 & 0.33 \\
\hline Thr & 94.0 & 82.1 & 84.5 & 79.8 & 9.49 & 0.21 & 0.12 & 0.19 \\
\hline Val & 86.5 & 87.6 & 93.0 & 83.4 & 4.34 & 0.57 & 0.15 & 0.09 \\
\hline Ala & 73.0 & 79.2 & 87.2 & 75.1 & 9.73 & 0.20 & 0.63 & 0.11 \\
\hline Asp & 84.7 & 85.8 & 88.5 & 79.5 & 8.29 & 0.28 & 0.15 & 0.11 \\
\hline Tyr & 85.9 & 73.3 & 89.6 & 80.6 & 9.74 & 0.18 & 0.10 & 0.36 \\
\hline Total AA & 83.2 & 84.5 & 88.2 & 82.6 & 4.82 & 0.34 & 0.26 & 0.15 \\
\hline EAA & 84.2 & 84.6 & 89.1 & 83.0 & 4.89 & 0.38 & 0.22 & 0.18 \\
\hline NEAA & 82.2 & 84.2 & 87.2 & 82.2 & 4.81 & 0.31 & 0.30 & 0.13 \\
\hline
\end{tabular}

\footnotetext{
${ }^{1}$ Alfalfa forage was harvested at a theoretical chop length of 19.1 or $7.9 \mathrm{~mm}$ for long- and short-cut silages, respectively.
} 
intestinal digestibility of RUP AA $(84.6 \pm 4.54 \%)$ than that of the total AA $(81.7 \pm 3.41 \%)$. The variation in the digestibility of individual AA is in agreement with studies using dairy cows (Yang and Beauchemin, 2004; Li et al., 2012a), sheep (Ben-Ghedalia and Solomon, 1988), or roosters fed feed residues after incubation in the rumen (Boucher et al., 2009; Fonseca et al., 2014). However, variation in the digestibility of individual AA was small for single feeds incubated in vitro (Mjoun et al., 2010) or in mobile bags inserted through a duodenal cannula and collected in feces (Paz et al., 2014). These results demonstrate differences in the intestinal digestibility of individual AA when determined in vitro (or in mobile bags) compared with in vivo.

\section{Milk Production and Composition}

Actual milk yield was decreased $(P=0.02)$ with increasing $\mathrm{F}: \mathrm{C}$ of the diet, and the effects of FPL depended upon F:C (interaction; $P=0.05$ ), with long FPL causing milk yield to decrease with the high F:C diet but not with the low F:C diet (Table 7). However, ECM was not affected by dietary treatment because milk components were affected by dietary treatments. Increasing $\mathrm{F}$ : $\mathrm{C}$ improved $(P<0.01)$ milk fat concentration, whereas the effect of FPL depended upon F:C ratio (interaction; $P=0.06$ ). Increased $\mathrm{FPL}$ increased milk fat concentration for the high $\mathrm{F}$ : $\mathrm{C}$ diet, but the opposite occurred for the low F:C diet. Despite changes in milk fat concentration, milk fat yield was not affected by diet. Additionally, interactions were observed between F:C and FPL for milk protein yield $(P=$ $0.04)$ and milk lactose yield $(P=0.07)$. Increasing $\mathrm{F}: \mathrm{C}$ decreased protein concentration and yield $(P<0.01)$, whereas increasing FPL only decreased protein yield for the high $\mathrm{F}: \mathrm{C}$ diet. Increasing $\mathrm{F}: \mathrm{C}$ tended $(P=0.07)$ to increase milk lactose concentration while decreasing milk lactose yield $(P=0.04)$, and long FPL decreased lactose yield only for the high $\mathrm{F}$ : $\mathrm{C}$ diet. These results are interpreted to suggest that the inclusion of long versus short FPL has only minor effects on milk production and composition with low F:C diets, but exerts greater effects with high F:C diets. The treatment effects on milk yield and milk composition from the 4 dairy cows used in this study were similar to those observed for all 12 cows used in the full experiment ( $\mathrm{Li}$ et al., 2020). However, the actual milk yield of the 4 cows $(26.5$ $\mathrm{kg} / \mathrm{d}$ ) was less than the average of all 12 cows (29.9 $\mathrm{kg} / \mathrm{d}$ ) because of smaller frame size and consequently lower DMI. Further details of the effects of F:C and FPL on milk production and composition are discussed in part 1 of the study (Li et al., 2020); thus, the discussion herein is focused on the relationship between the duodenal flows of AA and milk protein production.
Decreased milk, milk protein concentration and yield, and milk lactose yield with increased $\mathrm{F}$ : $\mathrm{C}$ were due to a deficit in energy supply due to decreased DMI and resulting amount of RDOM. The daily nutrient requirement for intake of $\mathrm{DM}$ and $\mathrm{NE}_{\mathrm{L}}$ was estimated at 22.5 $\mathrm{kg}$ and 32.0 Mcal (NRC, 2001), respectively, whereas intake of $\mathrm{DM}$ and $\mathrm{NE}_{\mathrm{L}}$ by cows fed the high $\mathrm{F}$ : $\mathrm{C}$ diets was $19.2 \mathrm{~kg}$ and $30.9 \mathrm{Mcal}$, respectively. Sutton (1989) reported milk protein content can be depressed by 0.1 to 0.4 percentage units due to dietary energy deficit. In the present study, decreased milk protein concentration and protein yield of cows fed low F:C diets appears not to be caused by a decreased supply of protein and AA. In fact, milk protein yield of cows fed low F:C diets $(0.80 \mathrm{~kg} / \mathrm{d})$ was less than $(0.9 \mathrm{~kg} / \mathrm{d}$; Broderick et al., 2007; Brito et al., 2007) or similar to $(0.82 \mathrm{~kg} / \mathrm{d}$; Brito et al., 2014) values reported by others, yet the amount of total AA flow to the duodenum $(2,373 \mathrm{~g}$ of total AA/d) was comparable or even higher $(2,250 \mathrm{~g}$ of total AA/d; Brito et al., 2014) than in other studies. Rumen microbial protein has an AA profile that closely resembles that of milk protein (Santos et al., 1998). Therefore, it is suggested that increased milk protein yield due to increased dietary energy content is associated with increased microbial protein flow to the duodenum (Mackle et al., 2000). Although microbial protein and AA flows decreased with high F:C diets, the differences in their intestinal digestibilities were minimal among treatments in the present study.

Furthermore, Lys and Met have been considered as the most limiting AA for lactating dairy cow diets. The NRC (2001) suggested that maximal milk protein production is achieved by formulating diets at concentrations of 7.2 and $2.4 \%$ of MP for Lys and Met, respectively, which corresponds to a ratio of Lys to Met of $3: 1$. The ratio of Lys to Met was greater than $3: 1$ in the current study (from 4.1 to 5.5). Patton (2010) concluded in a meta-analysis that rumen protected Met supplementation $(2.35 \%$ MP) increased milk protein concentration and yield, but Lys at $7.3 \% \mathrm{MP}$ was not required for this response. In addition, His has been identified as an AA that may increase milk production (Lee et al., 2012). Giallongo et al. (2015) observed no response to rumen protected Met supplementation when a MP-deficient diet based on corn silage was fed, but when rumen-protected Met and His were supplemented together, milk protein concentration and yield increased. Doepel et al. (2004) recommended a dietary His concentration of $2.4 \%$ of MP. The His concentration in duodenal protein was 2.44 and $2.08 \%$, respectively, for low and high F:C diets in the present study, suggesting that decreased milk protein concentration and yield for high F:C diets might also be due to low His supply. Nevertheless, in the present study, the protein 
Table 7. Effects of forage-to-concentrate ratio (F:C) and forage particle length (FPL) on milk production and composition for lactating dairy cows

\begin{tabular}{|c|c|c|c|c|c|c|c|c|}
\hline \multirow[b]{3}{*}{ Item } & \multicolumn{4}{|c|}{$\mathrm{F}: \mathrm{C}^{1}$} & \multirow[b]{3}{*}{$\mathrm{SE}$} & \multirow{2}{*}{\multicolumn{3}{|c|}{$P$-value }} \\
\hline & \multicolumn{2}{|c|}{$35: 65$} & \multicolumn{2}{|c|}{$60: 40$} & & & & \\
\hline & Short & Long & Short & Long & & $\mathrm{F}: \mathrm{C}$ & FPL & $\mathrm{F}: \mathrm{C} \times \mathrm{FPL}$ \\
\hline \multicolumn{9}{|l|}{ Milk yield, $\mathrm{kg} / \mathrm{d}$} \\
\hline Actual & $27.3^{\mathrm{a}}$ & $27.9^{\mathrm{a}}$ & $26.7^{\mathrm{a}}$ & $24.5^{\mathrm{b}}$ & 1.67 & 0.02 & 0.23 & 0.05 \\
\hline $4 \% \mathrm{FCM}^{2}$ & 24.3 & 24.3 & 24.3 & 23.4 & 1.67 & 0.35 & 0.30 & 0.28 \\
\hline $\mathrm{ECM}^{2}$ & 24.2 & 24.4 & 24.1 & 22.8 & 1.84 & 0.16 & 0.29 & 0.15 \\
\hline \multicolumn{9}{|l|}{ Milk fat } \\
\hline$\%$ & 3.26 & 3.13 & 3.42 & 3.70 & 0.129 & $<0.01$ & 0.44 & 0.06 \\
\hline $\mathrm{kg} / \mathrm{d}$ & 0.89 & 0.87 & 0.91 & 0.91 & 0.069 & 0.19 & 0.56 & 0.79 \\
\hline \multicolumn{9}{|l|}{ Milk protein } \\
\hline$\%$ & 3.27 & 3.33 & 3.15 & 3.10 & 0.046 & $<0.01$ & 0.80 & 0.17 \\
\hline $\mathrm{kg} / \mathrm{d}$ & $0.89^{\mathrm{ab}}$ & $0.93^{\mathrm{a}}$ & $0.84^{\mathrm{b}}$ & $0.76^{\mathrm{c}}$ & 0.054 & $<0.01$ & 0.40 & 0.04 \\
\hline \multicolumn{9}{|l|}{ Milk lactose } \\
\hline$\%$ & 4.50 & 4.48 & 4.55 & 4.52 & 0.087 & 0.07 & 0.27 & 0.61 \\
\hline $\mathrm{kg} / \mathrm{d}$ & 1.23 & 1.25 & 1.21 & 1.10 & 0.086 & 0.04 & 0.21 & 0.07 \\
\hline \multicolumn{9}{|l|}{ Milk efficiency } \\
\hline Actual/DMI & 1.25 & 1.25 & 1.39 & 1.31 & 0.113 & 0.12 & 0.52 & 0.53 \\
\hline FCM/DMI & 1.11 & 1.09 & 1.27 & 1.25 & 0.111 & 0.02 & 0.71 & 0.91 \\
\hline ECM/DMI & 1.11 & 1.09 & 1.22 & 1.22 & 0.121 & 0.05 & 0.89 & 0.71 \\
\hline $\mathrm{SCC}, \times 10^{5}$ & 1.27 & 1.14 & 1.38 & 1.40 & 0.890 & 0.12 & 0.61 & 0.47 \\
\hline
\end{tabular}

${ }^{\mathrm{a}-\mathrm{c}}$ Least squares means within a row with different superscripts differ $(P<0.05)$.

${ }^{1}$ Alfalfa forage was harvested at a theoretical chop length of 19.1 or $7.9 \mathrm{~mm}$ for long- and short-cut silages, respectively.

${ }^{2} \mathrm{FCM}$ was calculated as milk yield $(\mathrm{kg} / \mathrm{d}) \times[$ milk fat $(\%) \times 0.15+0.4] ; \mathrm{ECM}$ was calculated using the following equation: milk yield $(\mathrm{kg} / \mathrm{d}) \times\{[0.3887 \times$ milk fat $(\%)]+[0.2356 \times$ milk protein $(\%)]+[0.1653 \times$ milk lactose (\%)]\}/3.1338 (Moallem, 2016).

supply seemed to be sufficient to meet the requirement for milk protein production due to the high $\mathrm{CP}$ content of the diets and the high flows of AA.

\section{CONCLUSIONS}

Few interactions were observed between $\mathrm{F}$ :C and FPL for duodenal flows of AA and the intestinal digestibilities. Increasing the forage proportion of diets significantly decreased flows of AA to the duodenum as a result of decreased flows of microbial and feed AA as a consequence of decreased feed intake. As a result, the amount of AA digested in the intestine was less with high $\mathrm{F}$ : $\mathrm{C}$ than with low $\mathrm{F}: \mathrm{C}$ diets despite intestinal AA digestibility not being affected by F:C. In contrast, FPL had minimal effect on AA flow and digestibility in the intestine. These results indicate that AA supply were altered by manipulating dietary $\mathrm{F}$ : $\mathrm{C}$, but changing FPL had limited effects on AA supply. The results showed large variation in the digestibility of individual AA regardless of dietary treatment. These findings highlight the necessity of considering both flows and digestibility of individual AA for optimizing diet formulation to meet the AA requirements of dairy cows. Flows of AA to the duodenum had minimal effects on milk protein production even when energy supply was in deficit because the protein supply was sufficient.

\section{ACKNOWLEDGMENTS}

This experiment was financially supported by the Dairy of Farmers of Canada (Ottawa, ON) and Agriculture and Agri-Food Canada's (Ottawa, ON, Canada) Matching Investment Initiative. The authors thank K. Andrew, B. Farr, A. Furtado, D. Vedres, and R. Roth for their assistance in performing sampling and laboratory analyses, and as well as the staff of the Lethbridge Research Centre dairy unit for care of the cows. The authors have not stated any conflicts of interest.

\section{REFERENCES}

AOAC International. 2005. Official Methods of Analysis. 16th ed. AOAC Int., Arlington, VA.

Arndt, C., L. Armentano, and M. Hall. 2014. Corn bran versus corn grain at 2 levels of forage: Intake, apparent digestibility, and production responses by lactating dairy cows. J. Dairy Sci. 97:56765687. https://doi.org/10.3168/jds.2013-7815.

Arriola Apelo, S. I., J. R. Knapp, and M. D. Hanigan. 2014. Invited review: Current representation and future trends of predicting amino acid utilization in the lactating dairy cow. J. Dairy Sci 97:4000-4017. https://doi.org/10.3168/jds.2013-7392. 
Beauchemin, K. A., and W. Z. Yang. 2005. Effects of physically effective fiber on intake, chewing activity, and ruminal acidosis for dairy cows fed diets based on corn silage. J. Dairy Sci. 88:21172129. https://doi.org/10.3168/jds.S0022-0302(05)72888-5.

Ben-Ghedalia, D., and R. Solomon. 1988. Amino acids flow to and absorption from the small intestine of sheep fed barley and sulfur dioxide-treated straw at different ratios. Anim. Feed Sci. Technol. 22:147-159. https://doi.org/10.1016/0377-8401(88)90082-X.

Boucher, S., S. Calsamiglia, C. Parsons, H. Stein, M. Stern, P. Erickson, P. Utterback, and C. Schwab. 2009. Intestinal digestibility of amino acids in rumen undegradable protein estimated using a precision-fed cecectomized rooster bioassay: I. Soybean meal and SoyPlus. J. Dairy Sci. 92:4489-4498. https://doi.org/10.3168/jds .2008-1884.

Brito, A. F., G. A. Broderick, J. J. Olmos Colmenero, and S. M. Reynal. 2007. Effects of feeding formate-treated alfalfa silage or red clover silage on omasal nutrient flow and microbial protein synthesis in lactating dairy cows. J. Dairy Sci. 90:1392-1404. https://doi .org/10.3168/jds.S0022-0302(07)71625-9.

Brito, A. F., G. F. Tremblay, A. Bertrand, Y. Castonguay, G. Bélanger, R. Michaud, C. Lafrenière, R. Martineau, and R. Berthiaume. 2014. Alfalfa baleage with increased concentration of nonstructural carbohydrates supplemented with a corn-based concentrate did not improve production and nitrogen utilization in early lactation dairy cows. J. Dairy Sci. 97:6970-6990. https://doi.org/ 10.3168/jds.2013-7305.

Broderick, G. A., A. F. Brito, and J. J. Olmos Colmenero. 2007. Effects of feeding formate-treated alfalfa silage or red clover silage on the production of lactating dairy cows. J. Dairy Sci. 90:1378-1391. https://doi.org/10.3168/jds.S0022-0302(07)71624-7.

Canadian Council on Animal Care. 2009. Guide to the care and use of farm animals in research teaching and testing. E. D. Olfert, B. M. Cross, and A. A. McWilliam, ed. Can. Counc. Anim. Care, Ottawa, Ontario, Canada.

Chen, Z. H., G. A. Broderick, N. D. Luchini, B. K. Sloan, and E. Devillard. 2011. Effect of feeding different sources of rumen-protected methionine on milk production and N-utilization in lactating dairy cows. J. Dairy Sci. 94:1978-1988. https://doi.org/10.3168/jds.2010 -3578 .

Clark, J. H., T. Klusmeyer, and M. Cameron. 1992. Microbial protein synthesis and flows of nitrogen fractions to the duodenum of dairy cows. J. Dairy Sci. 75:2304-2323. https://doi.org/10.3168/ jds.S0022-0302(92)77992-2.

Doepel, L., D. Pacheco, J. J. Kennelly, M. D. Hanigan, I. F. Lopez, and H. Lapierre. 2004. Milk protein synthesis as a function of amino acid supply. J. Dairy Sci. 87:1279-1297. https://doi.org/10 .3168/jds.S0022-0302(04)73278-6.

Fessenden, S. W., T. J. Hackmann, D. A. Ross, E. Block, A. Foskolos, and M. E. Van Amburgh. 2019. Rumen digestion kinetics, microbial yield, and omasal flows of nonmicrobial, bacterial, and protozoal amino acids in lactating dairy cattle fed fermentation by-products or urea as a soluble nitrogen source. J. Dairy Sci. 102:3036-3052. https://doi.org/10.3168/jds.2018-15448.

Fessenden, S. W. T. J., T. J. Hackmann, D. A. Ross, A. Foskolos, and M. E. Van Amburgh. 2017. Ruminal bacteria and protozoa composition, digestibility, and amino acid profile determined by multiple hydrolysis times. J. Dairy Sci. 100:7211-7226. https://doi.org/10 .3168 /jds.2016-12531.

Firkins, J. L., L. L. Berger, N. R. Merchen, and G. C. Fahey Jr.. 1986. Effects of forage particle size, level of feed intake and supplemental protein degradability on microbial protein synthesis and site of nutrient digestion in steers. J. Anim. Sci. 62:1081-1094. https:// doi.org/10.2527/jas1986.6241081x.

Fonseca, A. C., S. M. Fredin, L. F. Ferraretto, C. M. Parsons, P. L. Utterback, and R. D. Shaver. 2014. Short communication: Intestinal digestibility of amino acids in fluid- and particle-associated rumen bacteria determined using a precision-fed cecectomized rooster bioassay. J. Dairy Sci. 97:3855-3859. https://doi.org/10.3168/jds .2013-7880.

Giallongo, F., A. N. Hristov, J. Oh, T. Frederick, H. Weeks, J. Werner, H. Lapierre, R. A. Patton, A. Gehman, and C. Parys. 2015. Effects of slow-release urea and rumen-protected methionine and histidine on performance of dairy cows. J. Dairy Sci. 98:3292-3308. https:/ /doi.org/10.3168/jds.2014-8791.

Guinard, J., and H. Rulquin. 1994. Effects of graded amounts of duodenal infusions of lysine on the mammary uptake of major milk precursors in dairy cows. J. Dairy Sci. 77:3565-3576. https://doi .org/10.3168/jds.S0022-0302(94)77300-8.

Hagen, S. R., B. Frost, and J. Augustin. 1989. Precolumn phenylisothiocyanate derivatization and liquid chromatograph of amino acids in food. J. Assoc. Off. Anal. Chem. 72:912-916.

Haque, M. N., H. Rulquin, A. Andrade, P. Faverdin, J. L. Peyraud, and S. Lemosquet. 2012. Milk protein synthesis in response to the provision of an "ideal" amino acid profile at 2 levels of metabolizable protein supply in dairy cows. J. Dairy Sci. 95:5876-5887. https://doi.org/10.3168/jds.2011-5230.

Hvelplund, T., and M. Hesselholt. 1987. Digestibility of individual amino acids in rumen microbial protein and undegraded dietary protein in the small intestine of sheep. Acta Agric. Scand. 37:469477. https://doi.org/10.1080/00015128709436578.

Ipharraguerre, I. R., and J. H. Clark. 2005. Impacts of the source and amount of crude protein on the intestinal supply of nitrogen fractions and performance of dairy cows. J. Dairy Sci 88:(E. Suppl.):E22-E37. https://doi.org/10.3168/jds.S0022 -0302(05)73134-9.

Ipharraguerre, I. R., and J. H. Clark. 2014. A Meta-analysis of ruminal outflow of nitrogen fractions in dairy cows. J. Adv. Dairy Res. 2:122. https://doi.org/10.4172/2329.88X.1000122.

Khorasani, G. R., E. K. Okine, and J. J. Kennelly. 2001. Effects of forage source and amount of concentrate on rumen and intestinal digestion of nutrients in late-lactation cows. J. Dairy Sci. 84:11561165. https://doi.org/10.3168/jds.S0022-0302(01)74576-6.

Kononoff, P. J., A. J. Heinrichs, and H. A. Lehman. 2003. The effect of corn silage particle size on eating behavior, chewing activities, and rumen fermentation in lactating dairy cows. J. Dairy Sci. 86:33433353. https://doi.org/10.3168/jds.S0022-0302(03)73937-X.

Krause, K. M., D. K. Combs, and K. A. Beauchemin. 2002. Effects of forage particle size and grain fermentability in midlactation cows. I. Milk production and diet digestibility. J. Dairy Sci. 85:19361946. https://doi.org/10.3168/jds.S0022-0302(02)74270-7.

Lee, C., A. N. Hristov, T. W. Cassidy, K. S. Heyler, H. Lapierre, G. A. Varga, M. J. de Veth, R. A. Patton, and C. Parys. 2012. Rumenprotected lysine, methionine, and histidine increase milk protein yield in dairy cows fed a metabolizable protein-deficient diet. J. Dairy Sci. 95:6042-6056. https://doi.org/10.3168/jds.2012-5581.

Li, C., K. A. Beauchemin, and W. Z. Yang. 2020. Feeding diets varying in forage proportion and particle length to lactating dairy cows: I. Effects on ruminal $\mathrm{pH}$ and fermentation, microbial protein synthesis, digestibility, and milk production. J. Dairy Sci. 103:4340-4354. https://doi.org/10.3168/jds.2019-17606.

Li, C., J. Li, K. Beauchemin, and W. Yang. 2012a. Forage proportion and particle length affects the supply of amino acids in lactating dairy cows. J. Dairy Sci. 95:2685-2696. https://doi.org/10.3168/ jds.2011-5210.

Li, C., J. Q. Li, W. Z. Yang, and K. A. Beauchemin. 2012b. Ruminal and intestinal amino acid digestion of distiller's grain vary with grain source and milling process. Anim. Feed Sci. Technol. 175:121-130. https://doi.org/10.1016/j.anifeedsci.2012.05.011.

Mackle, T. R., D. A. Dwyer, K. L. Ingvartsen, P. Y. Chouinard, D. A. Ross, and D. E. Bauman. 2000. Effects of insulin and postruminal supply of protein on use of amino acids by the mammary gland for milk protein synthesis. J. Dairy Sci. 83:93-105. https://doi.org/10 .3168/jds.S0022-0302(00)74860-0.

Maxin, G., D. R. Ouellet, and H. Lapierre. 2013. Ruminal degradability of dry matter, crude protein, and amino acids in soybean meal, canola meal, corn, and wheat dried distillers grains. J. Dairy Sci. 96:5151-5160. https://doi.org/10.3168/jds.2012-6392.

Mjoun, K., K. Kalscheur, A. Hippen, D. Schingoethe, and D. Little. 2010. Lactation performance and amino acid utilization of cows fed increasing amounts of reduced-fat dried distillers grains with solubles. J. Dairy Sci. 93:288-303. https://doi.org/10.3168/jds .2009-2377. 
Moallem, U. 2016. Future consequences of decreasing marginal production efficiency in high-yielding dairy cow. J. Dairy Sci. 99:29862995. https://doi.org/10.3168/jds.2015-10494.

Moorby, J. M., R. J. Dewhurst, R. T. Evans, and J. L. Danelon. 2006. Effects of dairy cow diet forage proportion on duodenal nutrient supply and urinary purine derivative excretion. J. Dairy Sci. 89:3552-3562. https://doi.org/10.3168/jds.S0022-0302(06)72395 $-5$.

NRC. 2001. Nutrient Requirements of Dairy Cattle. 7th rev. ed. Natl. Acad. Sci., Washington, DC. https://doi.org/10.17226/9825.

Osorio, J. S., P. Ji, J. K. Drackley, D. Luchini, and J. J. Loor. 2013. Supplemental Smartamine M or MetaSmart during the transition period benefits postpartal cow performance and neutrophil function. J. Dairy Sci. 96:6248-6263. https://doi.org/10.3168/jds.2012 -5790 .

Overton, T., M. Cameron, J. Elliottt, J. Clark, and D. Nelson. 1995. Ruminal fermentation and passage of nutrients to the duodenum of lactating cows fed mixture of corn and barley. J. Dairy Sci. 78:1981-1998. https://doi.org/10.3168/jds.S0022-0302(95)76824 -2 .

Patton, R. A. 2010. Effect of rumen-protected methionine on feed intake, milk production, true milk protein concentration, and true milk protein yield, and the factors that influence these effects: A meta-analysis. J. Dairy Sci. 93:2105-2118. https://doi.org/10 .3168/jds.2009-2693.

Paz, H. A., T. J. Klopfenstein, D. Hostetler, S. C. Fernando, E. Castillo-Lopez, and P. J. Kononoff. 2014. Ruminal degradation and intestinal digestibility of protein and amino acids in high-protein feedstuffs commonly used in dairy diets. J. Dairy Sci. 97:64856498. https://doi.org/10.3168/jds.2014-8108.

Rode, L., and L. Satter. 1988. Effect of amount and length of alfalfa hay in diets containing barley or corn on site of digestion and rumen microbial protein synthesis in dairy cows. Can. J. Anim. Sci. 68:445-454. https://doi.org/10.4141/cjas88-050.

Rode, L., D. Weakley, and L. Satter. 1985. Effect of forage amount and particle size in diets of lactating dairy cows on site of digestion and microbial protein synthesis. Can. J. Anim. Sci. 65:101-111. https: //doi.org/10.4141/cjas85-011.

Rulquin, H., and R. Vérité. 1993. Amino acid nutrition of dairy cows: Production effects and animal requirements. Pages 55-77 in Recent Advances in Animal Nutrition. P. C. Garnsworthy and D. J. A. Cole, ed. Nottingham University Press, Nottingham, UK.
Santos, F. A. P., J. E. P. Santos, C. B. Theurer, and J. T. Huber. 1998. Effects of rumen-undegradable protein on dairy cow performance: A 12-year literature review. J. Dairy Sci. 81:3182-3213. https://doi .org/10.3168/jds.S0022-0302(98)75884-9.

Schwab, C. G. 2010. Balancing diets for amino acids: Nutritional, environmental and financial implications. Pages 1-13 in Proc. TriState Dairy Nutr. Conf., Ft. Wayne, IN. The Ohio State University, Columbus.

Schwab, C. G., C. K. Bozak, N. L. Whitehouse, and M. M. A. Mesbah. 1992. Amino acid limitation and flow to duodenum at four stages of lactation. 1. Sequence of lysine and methionine limitation. J. Dairy Sci. 75:3486-3502. https://doi.org/10.3168/jds.S0022 -0302(92)78125-9.

Sok, M., D. R. Ouellet, J. L. Firkins, D. Pellerin, and H. Lapierre. 2017. Amino acid composition of rumen bacteria and protozoa in cattle. J. Dairy Sci. 100:5241-5249. https://doi.org/10.3168/ jds.2016-12447.

Sutton, J. D. 1989. Altering milk composition by feeding. J. Dairy Sci. 72:2801-2814. https://doi.org/10.3168/jds.S0022-0302(89)79426 $-1$.

White, R. R., P. J. Kononoff, and J. L. Firkins. 2017. Technical note: Methodological and feed factors affecting prediction of ruminal degradability and intestinal digestibility of essential amino acids. J. Dairy Sci. 100:1946-1950. https://doi.org/10.3168/jds.2016-12008.

Yang, W. Z., and K. A. Beauchemin. 2004. Grain processing, forage-to-concentrate ratio, and forage length effects on ruminal nitrogen degradation and flows of amino acids to the duodenum. J. Dairy Sci. 87:2578-2590. https://doi.org/10.3168/jds.S0022 -0302(04)73383-4.

Yang, W. Z., K. A. Beauchemin, and L. Rode. 2001. Effect of dietary factors on distribution and chemical composition of liquidor solid-associated bacterial populations in the rumen of dairy cows. J. Anim. Sci. 79:2736-2746. https://doi.org/10.2527/2001 $.79102736 x$.

\section{ORCIDS}

S. M. Yan ํㅏ https://orcid.org/0000-0002-4107-2858

K. A. Beauchemin (1) https://orcid.org/0000-0002-5070-4554

W. Z. Yang (ํ) https://orcid.org/0000-0001-9453-924X 